\title{
Muscular injuries after tendon rupture in the rotator cuff of animal models. Systematic review
}

\author{
Verónica Montiel Terrón ${ }^{1}$ \\ Emma Muiños-López ${ }^{2}$ \\ Froilán Granero-Moltó ${ }^{1,2}$ \\ Manuel Alegre Esteban ${ }^{3}$ \\ Felipe Prosper 2,4 \\ Ana Pérez-Ruiz ${ }^{4}$ \\ Juan Pons-Villanueva ${ }^{1}$
}

1 Orthopaedic Surgery and Traumatology Department, Clínica Universidad de Navarra, Pamplona, Spain

2 Cell Therapy Area, Clínica Universidad de Navarra, Pamplona, Spain

3 Neurophysiology Department, Clínica Universidad de Navarra, Pamplona, Spain

${ }^{4}$ Regenerative Medicine, Center of Medicine for Medical Application, Pamplona, Spain

Corresponding author:

Juan Pons-Villanueva

Orthopaedic Surgery and Traumatology Department,

Clínica Universidad de Navarra

Av. Pío XII, 36

31008 Pamplona (Navarra), Spain

E-mail: jponsdevi@unav.es

\section{Summary}

Introduction: Atrophy, fatty infiltration and fibrosis are irreversible changes of the muscle after chronic retraction of a torn tendon. These changes result in further loss of function and are prognostic factors for worse clinical outcomes after surgical repair, making such approach ineffective. Currently, there is no clinical treatment to reverse this degenerative condition. This review addresses the findings of experimental studies in the context of the molecular regulation and the cellular origin of the local fibro/adipogenic progenitors and satellite cells.

Methods: We systematically reviewed studies on animal models of muscular degeneration after lesion of the tendons of the rotator cuff. We used PubMed as data source. Eligibility criteria were animal models assessing the degeneration of rotator cuff muscles after tendon injury or repair. The articles were reviewed for experimental methodology of the lesion, control group and tim- ing of repair.

Results: The experimental studies addressing muscle-tendon retraction have reproduced and described muscular changes at the macroscopic, histologic, biochemical and genetic level. With the aim to improve this condition, some possible surgical and pharmacological approaches have been investigated.

Conclusion: Animal models for muscular degeneration after rotator cuff tears have been well established and described. The next challenge is the achievement of a therapeutic target that could be transferred to the clinical setting.

Level of evidence: Not applicable.

KEY WORDS: fatty infiltration, fibro/adipose progenitors, fibrosis, muscle atrophy.

\section{Introduction}

The degeneration of the muscles of the rotator cuff worsens the function of the shoulder after tendon rupture and jeopardizes the results of surgical treatment. To date there is not an established clinical treatment for the prevention or improvement of muscular degeneration ${ }^{1}$.

The objective of this review is to compile the current knowledge in animal models of the muscular consequences of rotator cuff tendon tears, specially atrophy, how it starts and progresses, the role of muscular stem cells, and how fibrosis and fatty infiltration compromise muscle regeneration. We also review the influence of surgical repair and pharmacological interventions as compared to experimental control groups. The outcome of interest is the effect on atrophy, fibrosis and fatty infiltration. We include all the experimental studies and some clinical studies relevant to the question. Thus, the review will start with the observations from human samples and then goes into details of the current animal models. Finally, the features of muscular degeneration are discussed.

\section{Materials and methods}

According to PRISMA guidelines a systematic strategy was used for previous publications on animal models were searched in the PubMed database (September $\left.8^{\text {th }} 2017\right)^{2}$. The search strategy was tendon AND 
(rotator cuff OR supraspinatus) AND [(fatty OR adipo*) OR (atrophy) OR (fibrosis)]. The selection criteria were original studies on animal models assessing the degeneration of rotator cuff muscles in experimental modelling or treatment of muscle degeneration, tendon injury or repair. Articles in English or French were included. The study selection was done by one of the Authors (JPV). References within articles were also screened for inclusion. The references of review articles were also screened.

The data was collected by two of the Authors (VMT, JPV). The articles were reviewed for experimental methodology of the lesion, intervention, control group, timing of repair (when applicable). The variability in animal species, methodologies and timing precluded quantitative summarizing of data.

Studies on human samples indirectly detected by means of this search strategy have been included for detailing of background information.

This research was conducted according to the international standards ${ }^{3}$.

\section{Results}

The search strategy yielded 655 references. The flow diagram of study selection is detailed in Figure 1.

\section{Basic-science studies of the muscle of the torn rotator cuff in human samples}

The presence of apoptosis, necrosis, protein catabolism, loss of satellite cells and changes in molecular receptors determine the atrophic muscular injuries. This process is further aggravated by the development of fibrotic and adipose cells within the muscle.

Biopsies from patients have shown that muscle atrophy is characterized by accumulation of fibers with decreased cross sectional area and increased percentage of small-diameter fibers ${ }^{4-7}$. Lundgreen et al. studied the distribution and fiber composition by immunohistochemistry. In full thickness tears, both $\mathrm{MHC}_{1}{ }^{+}$and $\mathrm{MHC}_{2}{ }^{+}$fibers have smaller average diameters than in partial thickness tears, with a decreased proportion of type I $\left(\mathrm{MHC}^{+}\right)$fibers ${ }^{5,8}$. Using electron microscopy, Steinbacher et al. observed that the decrease in cross sectional area is exclusive of type I (slow) fibers. In addition they have higher mitochondrial volume density, a common feature of atrophic muscle 6 . Fuchs et al. demonstrated upregulation of myosin heavy polypeptide-1 mRNA expression levels, which expresses type IIx myosin characteristic of type II (fast) fibers ${ }^{9}$.

One of the key factors in skeletal muscle maintenance and repair is the presence of the satellite cells ${ }^{10,11}$. In comparison with partial thickness tears, full thickness tears have a smaller population of satellite cells, and these cells are less actively replicating in injured tendons ${ }^{8}, 12,13$. This is in accordance to the findings of Gigliotti et al., who observed that non-proliferating satellite cells ( $\left.\mathrm{Pax} 7^{+/} / \mathrm{BrdU}^{-}\right)$were more abundant than the proliferating $\mathrm{Pax} 7^{+} / \mathrm{BrdU}^{+}$ones $^{7}$.
However, satellite cells which lack a proliferating stimulus in this specific clinical entity maintained their ability to differentiate, fusing in culture and generating new fibers when delivered into injured muscles ${ }^{12}$. In conclusion, the progenitor cells population is less abundant and more compromised to replicate rather than to regenerate ${ }^{13}$.

Fibrosis and fatty infiltration are two cellular processes which characterize human muscle response in rotator cuff tears, as well as in other pathologies such as bursitis and tendinopathy ${ }^{14}$. The tissue samples of injured rotator cuffs show increased fibrosis and fat tissue composition $5,15,16$. Curiously, muscles from massive tears show downregulated fibrogenic, adipogenic and myogenic genes, while those from full thickness tears upregulate fibrotic and adipogenic genes and down regulate myogenic genes. These changes correlate with MRI imaging ${ }^{17}$. Muscles from shoulders with bursitis or tendinopathy still express myogenic genes ${ }^{14}$. Fatty infiltration is mainly located between fibers, and it is more noticeable in full thickness tears than in partial thickness tears ${ }^{8}$. Consequently, lipid content is also increased inside the cells, specifically in type I fibers ${ }^{6}$. Fibrosis is characterized by an increase in collagen content, which may be explained by the upregulation of alpha smooth muscle actin ( $\alpha S M A)$ (implied in pro-fibrotic processes) ${ }^{6,9,15}$. In addition, collagen deposition may explain the biomechanical response of the musculotendinous unit to chronic ruptures: an increased passive tension, indicating tendon retraction. It requires greater force to reduce the tendon stump to its original insertion $^{18}$. The late stage shows further degeneration with the presence of macrophages ${ }^{19}$

At the molecular level, excessive protein destruction resulting from accelerated turnover of proteins by the ubiquitin-proteasome pathway, often coupled with diminished rates of protein synthesis seems to be the main mechanism behind muscle atrophy ${ }^{20}$. The Forkhead box O (FOXO) family proteins promote muscle atrophy not only by inducing the proteasome pathway, but also acting on the autophagy lysosomal system, indicating that these two catabolic pathways often work together ${ }^{21}$. In addition, the caspase and calpain protein families, commonly known for their role in initiating apoptosis, are proteolytic enzymes which participate in protein catabolism. Human biopsies of massive rotator cuff tears exhibit upregulation of some genes involved in protein degradation. Atrogin1 (MAFbx) has been shown to be increased, and expression levels of Capn1, Ube2b, and Ube3a were upregulated more than two-fold after injury ${ }^{5,22}$.

\section{Denervation secondary to musculo-tendinous injury}

Warner et al. raised the concern that repair of a retracted rotator cuff could lead to indirect iatrogenic injury of the suprascapular nerve (SSN) ${ }^{23}$. In fact, Goutallier et al. observed SSN injury after repair of retracted supraspinatus tendons ${ }^{24}$. However Mallon et al. observed re-innervation after repair of massive rotator cuff tears with concomitant SSN injury ${ }^{25}$. 


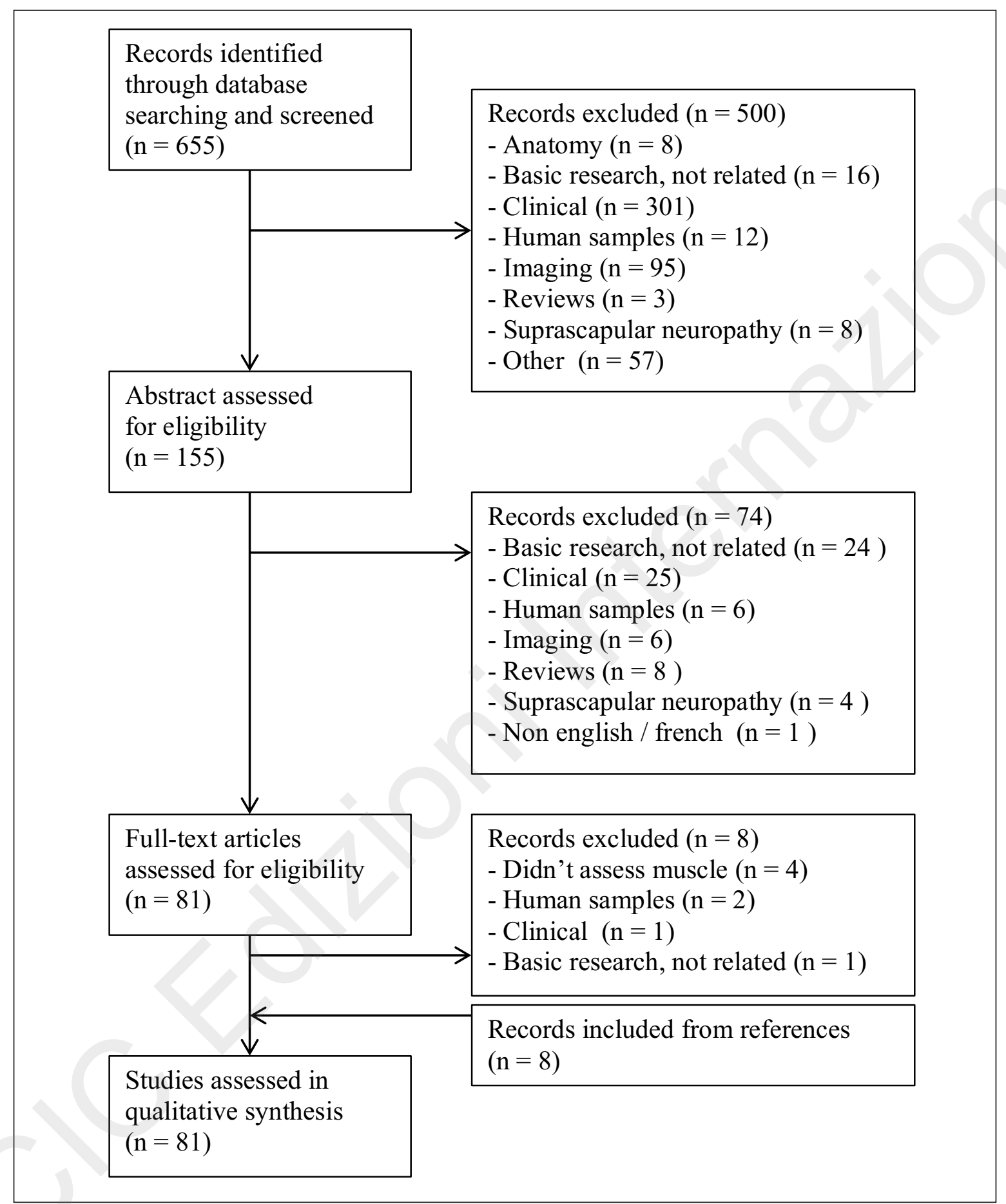

Figure 1. Flow chart of the study selection.

Despite studies showing a low incidence of SSN injury in rotator cuff tears and the presence of SSN injury being independent of the fatty infiltration, retraction of the rotator cuff has been postulated to lead to secondary compression neuropathy of the SSN26-30. Interestingly Beeler et al. observed that the pattern of fatty infiltration in rotator cuff tears is different from the one found associated to SSN injury ${ }^{31}$. Other stud- ies showing a higher prevalence of SSN are subject to selection bias ${ }^{32}$. Gigliotti et al. didn't find any differences between the neuromuscular junctions (Acetylcholine receptor) AChR cluster pattern in torn supraspinatus and healthy deltoid muscle. However, the muscle of torn supraspinatus showed a tendency toward a higher $\gamma / \varepsilon$ AChR subunit ratio, which suggests that there is denervation of the muscle ${ }^{7}$. 
In conclusion, in humans, after rotator cuff injury, muscle atrophy is characterized by decreased diameter of muscular fibers, especially type I fibers, and increase in the proportion of type II fibers. The population of satellite cells is small and show less replication. These changes are aggravated by fibrosis and fatty infiltration. Finally, there is an upregulation of the expression of genes mediating protein degradation and an increase of protein catabolism.

\section{Experimental models of muscular lesion of the ro- tator cuff}

Methods used for the description of the phenomenon The high variability among the studies due to the animal model used, injury method, timing and analysis technique makes difficult to summarize the design of different animal models and surgical procedures that assess the changes in the muscle after a tendon lesion (Tab. I).

The main animal models have been developed in sheep, rabbit and rat. More recently, a mouse model has been described. The surgical methods to produce a tendon tear include osteotomy, simple transection, resection, transection and release from neighbouring tendons of the rotator cuff and wrapping of the tendon to prevent healing (Tab. I). Some studies assessed the effect of surgical repair on muscle response at different time points after the initial injury: straightaway after injury, early or late, depending on the animal model. Another variability factor between animal models is the timing of sampling since the injury or repair surgery.

The muscle atrophy, fatty infiltration, muscle retraction, fibrosis, denervation, and inflammation were assessed using a variety of methods including macroscopic description, CT imaging, MRI, histology and electron microscopy. Recently, the presence of different proteins has been assessed by immunohistochemistry, immunofluorescence, western blot and quantitative PCR.

Changes after experimental lesions in different animals have different time course and intensity, therefore the most relevant aspects will be commented stratified by animal species.

\section{Atrophy}

Sheep. In sheep, the muscle atrophy after tenotomy develops increased fiber diameter while the mean muscle fiber length decreases due to the change in the pennation angle ${ }^{34,36}$. Although atrophy lingers after late repair, it improves after continuous traction with an increase in type II fibers ${ }^{35,36}$. At the molecular level, these changes are correlated with changes of some myogenic transcription factors as well as with muscle growth related factors. Expression of Myf-5 increases, while myogenin and myostatin remained unchanged $^{37}$, which suggests that satellite cells are in a quiescent-like state rather than cycling and undergoing differentiation. The atrophic changes are much increased when a lesion to the suprascapular nerve is added to the animal model ${ }^{41}$.

Rabbit. In rabbits, there is also muscle atrophy with decreased volume, tissue weight, fiber cross sectional area and Type I fibers 47,48 . These changes occur earlier and are more pronounced in large tendon releases (free retraction tenotomy), progressing up to 12 months after tenotomy 46,50 . Twelve weeks after surgical repair, the muscle atrophy persists but it may be reversed 24 weeks after repair ${ }^{47,57}$.

Rat. Triggering lasting muscular changes in rats requires lesion and release of at least two tendons. When a simple SSP release is done, some of the muscle atrophic changes recover healing spontaneously eight/nine weeks after injury $58,59,64$. Ward et al. found a decrease in cross sectional area of myofibers together with a reduced number of sarcomeres when the supraspinatus tendon is released ${ }^{59}$. The decreased fiber cross sectional area found at earlier stages, further decreased in later stages ${ }^{79}$. As in rabbits, muscle atrophy was characterized by higher ratio of type Ilb fibers ${ }^{65}$. Additional histological analysis showed absence of fibers with shrunken centralized nuclei, which are forming clusters twelve weeks after tendon injury, demonstrating the absence of a regeneration process 66,70 .

Atrophic muscles characterize the muscular degeneration after tenotomy with a higher proportion in type II fibers $^{66}$. However, when suprascapular neurotomy is added to the tenotomy, the fiber type distribution pattern is completely different (with increased type I fibers) to the one found in muscles after simple tenotomy. Following doubled injury, Myh7 (MHC I) expression first decreases and finally increases, while expression levels of Myh4 (MHC Ilb) starts increasing and then decreases ${ }^{66}$. These changes correlate with an upregulation of MyoD1 expression, and a downregulation of Myf5 and myostatin.

Regarding the mechanisms responsible of muscle atrophy, it has been shown that tenotomy is followed by a decrease in protein levels of $p$-AKT, p-mTOR, p$70 S 6$ Kinase and p-FOXO1, despite having unchanged total levels of protein ${ }^{67}$. Expression of MAFbx and MuRF-1, two muscle-specific ubiquitin ligase genes, remains unchanged after tenotomy ${ }^{65,67}$. The AKT/mTOR pathway is a central regulator of muscle atrophy due to its ability to regulate muscle protein synthesis and degradation, and S6k1 and FOXO translocations. Once AKT becomes activated, mTOR phosphorylates and activates, which further regulates protein synthesis via 4E-BP-1 and S6K1. Furthermore, decreased activation and phosphorylation of AKT promotes reduced phosphorylation of FoxO, which is able to translocate to the nucleus and initiate the transcription of autophagy-related genes. In summary, muscle atrophy after tenotomy seems related to reduction of protein synthesis via decreased S6K1 activity rather than protein catabolism. 
Table I. Animal models for muscle injury after rotator cuff tendon injury.

\begin{tabular}{|c|c|c|c|c|}
\hline Animal & Reference & Tenotomy & Control & Repair \\
\hline \multirow{8}{*}{$\begin{array}{l}\frac{0}{\Phi} \\
\frac{\mathscr{N}}{\omega}\end{array}$} & Coleman et al. $2003^{33}$ & ISP release and cover in gore-tex & WO & W0, W6, W18 \\
\hline & Meyer et al. $2004{ }^{34}$ & ISP osteotomy, encased in silicon tube & CLS & W40 \\
\hline & Gerber et al. $2004{ }^{35}$ & ISP osteotomy, encased in silicon tube & CLS & W40 \\
\hline & Gerber et al. $2009^{36}$ & ISP osteotomy, encased in silicon tube & CLS & W22 \\
\hline & $\begin{array}{l}\text { Frey et al. } 200937 \\
\text { Zumstein et al. } 2012{ }^{38}\end{array}$ & & Failed repairs & \\
\hline & Meyer et al. $2011^{39}$ & ISP osteotomy, encased in silicon tube & CLS & --- \\
\hline & Luan et al. $2015^{40}$ & ISP tenotomy & CLS & WO \\
\hline & Gerber et al. $2017^{41}$ & $\begin{array}{l}\text { ISP osteotomy, encased in silicon tube } \\
\pm \text { SSN neurectomy }\end{array}$ & CLS & W6 \\
\hline Dog & Safran et al. $2005^{42}$ & $\begin{array}{l}\text { ISP release+wrap with polymer } \\
\text { membrane }\end{array}$ & CLS & --- \\
\hline \multirow{15}{*}{ 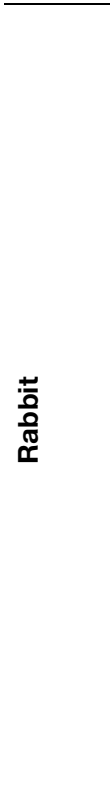 } & Bjorkenheim 198943 & $\begin{array}{l}\text { SSP release and allowed to freely } \\
\text { retract }\end{array}$ & CLS & --- \\
\hline & Fabis et al. $1998^{44}$ & Supraspinatus detachment & 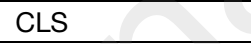 & --- \\
\hline & Fabis et al. $2000^{45}$ & SSP detachment & CLS & --- \\
\hline & Fabis et al. $2001^{46}$ & SSP detachment & 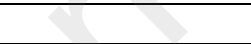 & --- \\
\hline & Matsumoto et al. $2002{ }^{47}$ & SSP detachment + wrapping & SG (no repair) & W12 \\
\hline & Uhthoff et al. $2003^{48}$ & SSP detachment + wrapping & $\begin{array}{l}\text { CLS detachment } \\
\text { SG (no repair) }\end{array}$ & W6 \\
\hline & Gupta et al. $2007^{49}$ & $\begin{array}{l}\text { SSC detachment } \\
\text { Partial or complete or neurotomy }\end{array}$ & CLS & --- \\
\hline & Rubino et al. 200750 & SSP detachment and release & CLS intact & --- \\
\hline & Rubino et al. $2008^{51}$ & SSP detachment and release & CLS intact & W6 \\
\hline & Rowshan et al. $2010^{52}$ & $\begin{array}{l}\text { SSC superior section or } \\
\text { Complete or } \\
\text { nerve section }\end{array}$ & CLS sham surgery & --- \\
\hline & Trudel et al. $2010^{53}$ & SSP detachment \& wrapping & SG intact & $-\cdots$ \\
\hline & Trudel et al. $2012^{54}$ & SSP detachment & SG intact & W4, W8, W12 \\
\hline & Gayton et al. $2013^{55}$ & SSP detachment and release & CLS & $-\ldots$ \\
\hline & Uhthoff et al. $2014{ }^{56}$ & Detachment + repair & SG & Wo \\
\hline & Fabis et al. $2016^{57}$ & $\begin{array}{l}\text { SSP, fibrocartilaginous pad was } \\
\text { resected }\end{array}$ & CLS & W12 \\
\hline \multirow{12}{*}{$\begin{array}{l}\stackrel{\pi}{\pi} \\
\mathscr{\sim}\end{array}$} & Barton et al. $2005^{58}$ & SSP tenotomy (no release) & SG & --- \\
\hline & Ward et al. $2010^{59}$ & SSP release & CLS & --- \\
\hline & Buchman et al. 201160 & SSP TT & CLS intact & --- \\
\hline & Itoigawa et al. $2011^{61}$ & SSP ISP resection, SSC detachment & CLS sham surgery & --- \\
\hline & Farshad et al. $2011^{62}$ & SSP tenotomy & CLS sham surgery & --- \\
\hline & Liu et al. 201163 & $\begin{array}{l}\mathrm{SSP}+\mathrm{SP}+\mathrm{TM} \text { resection or } \\
\mathrm{SSP}+\mathrm{SP}+\mathrm{TM} \text { resection+SSN } \\
\text { neurotomy }\end{array}$ & CLS sham surgery & --- \\
\hline & Mannava et al. $2011^{64}$ & SSP tenotomy & SG & --- \\
\hline & Gumucio et al. $2012^{65}$ & $\mathrm{SSP}+\mathrm{ISP}$ resection & CLS sham surgery & --- \\
\hline & Kim et al. 201266 & $\begin{array}{l}\mathrm{SSP} \\
\mathrm{SSP}+\mathrm{ISP} \\
\mathrm{SSP}+\mathrm{ISP}+\mathrm{SSN} \\
\text { Control (no surgery) }\end{array}$ & SG & --- \\
\hline & Liu et al. $2012^{67}$ & $\begin{array}{l}\text { SSP + ISP resection } \\
\text { or SSN neurotomy } \\
\text { Control (unoperated) }\end{array}$ & $\begin{array}{l}\text { SG intact } \\
\text { CLS sham surgery }\end{array}$ & --- \\
\hline & Joshi et al. $2013^{68}$ & $\mathrm{SSP}+\mathrm{ISP}+\mathrm{SSN}$ & CLS & --- \\
\hline & Killian et al. $2013^{69}$ & $\begin{array}{l}\text { SSP TT or } \\
\text { SSP TT + repair or } \\
\text { SSP TT + repair + botulinum toxin }\end{array}$ & $\begin{array}{l}\text { SG intact, } \\
\text { Saline injection } \\
\text { Toxin injection }\end{array}$ & D0 \\
\hline
\end{tabular}


Continue from Table I.

\begin{tabular}{|c|c|c|c|c|}
\hline & Ditsios et al. $2014^{70}$ & SSP + ISP detachment & CLS & --- \\
\hline & Gumucio et al. $2014{ }^{71}$ & SSP + ISP resection. & CLS sham surgery & --- \\
\hline & Ichinose et al. $2014^{72}$ & SSP release and resection & SG intact & --- \\
\hline & Joshi et al. $2014^{73}$ & $\begin{array}{l}\text { SSP ISP tendon resection } \\
\text { SSN resection }\end{array}$ & CLS sham surgery & --- \\
\hline & Killian et al. $2014{ }^{74}$ & SSP + ISP TT + chronic repair & SG acute injury+repair & W0, W8, W16 \\
\hline & Liu et al. $2014^{75}$ & $\mathrm{SSP}+\mathrm{ISP}+\mathrm{SSN}$ transection & CLS sham surgery & --- \\
\hline & Sato et al. $2014^{76}$ & $\begin{array}{l}\text { SSP ISP TT + saline } \\
\text { SSP ISP TT + botulinum toxin }\end{array}$ & SG intact & --- \\
\hline & Davies et al. $2015^{77}$ & $\begin{array}{l}\text { SSP ISP TT + SSN } \\
\text { Achilles + sciatic nerve section }\end{array}$ & CLS sham surgery & -- \\
\hline & Davis et al. $2015^{78}$ & SSP TT & SG & D28 \\
\hline & Killian et al. $2015^{79}$ & $\begin{array}{l}\text { SSP IST TT + botulinum toxin+W8 } \\
\text { repair } \\
\text { SSP IST TT + W0 repair }\end{array}$ & CLS acute repair & W0, w8 \\
\hline & Liu et al. $2015^{80}$ & SSP + ISP resection + SSN neurotomy & CLS sham surgery & --- \\
\hline & Melamed et al. $2015^{81}$ & SSP TT & CLS (group B) & WO \\
\hline & Sahin et al. $2015^{82}$ & SSP TT & SG intact & WO \\
\hline & Sevivas et al. $2015^{83}$ & SSP ISP detachment & SG sham surgery & --- \\
\hline & Davies et al. $2016^{84}$ & SSP ISP TT + SSN resection & CLS sham surgery & --- \\
\hline & Hashimoto et al. $2016^{85}$ & SSP ISP TT & CLS sham surgery & --- \\
\hline & Thangarajah et al. $2017^{86}$ & SSP TT & CLS & --- \\
\hline \multirow{8}{*}{ 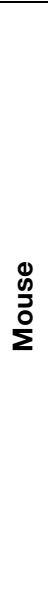 } & Kim et al. 201266 & $\begin{array}{l}\text { SSP + ISP detachment or } \\
\text { SSP + ISP detachment + SSN } \\
\text { neurotomy }\end{array}$ & --- & --- \\
\hline & Liu et al. $2012^{87}$ & $\begin{array}{l}\text { SSP }+ \text { ISP resection or } \\
\text { SSN or } \\
\text { both }\end{array}$ & CLS sham surgery & --- \\
\hline & Samagh et al. $2013^{88}$ & $\begin{array}{l}\text { SSP + ISP resection or } \\
\text { SSN lesion or } \\
\text { both }\end{array}$ & CLS sham surgery & --- \\
\hline & Kuenzler et al. 201689 & SSP + ISP TT + SSN neurotomy & CLS & --- \\
\hline & Liu et al. $2016^{90}$ & SSP, ISP TT + SSN neurotomy & $\begin{array}{l}\text { CLS sham surgery } \\
\text { SG (C57BL/6) }\end{array}$ & --- \\
\hline & Davies et al. $2017^{91}$ & SSP + ISP resection & CLS sham surgery & --- \\
\hline & Klomps et al. $2017^{92}$ & $\begin{array}{l}\text { SSP + ISP resection } \\
\text { SSN neurotomy }\end{array}$ & SG & --- \\
\hline & Lee et al. $2017^{93}$ & SSP TT & CLS & --- \\
\hline
\end{tabular}

SSP supraspinatus, ISP: infraspinatus, SSC: subscapularis, SSN: supraescapular nerve, CLS: contralateral side; SG, specific group. D, day; W, week; M, month; S, sacrifice.

After denervation, both anabolic and catabolic pathways become activated with an increase expression of p-AKT, p-mTOR, p-70S6 Kinase, p-FOXO1 and up-regulation of the MuRF1 and MAFbx catalytic genes, which leads to severe muscle atrophy67. The up-regulation of AKT/mTOR/S6K1 signalling pathway may be compensatory due to the protein degradation caused by the increase of ubiquitin-proteasome activity. Thus, rotator cuff muscle atrophy following nerve injury is primarily caused by increased protein degradation instead of decreased protein synthesis, although the up-regulation of MuRF1 and MAFbx genes seems to be independent of FOXO activation ${ }^{67}$. As described in other injuries, muscle atrophy induced by mTOR, which is also associated to upregulation of PPARY and SREBP-1, can be modified by blocking mTOR signalling with Rapamycin $67,68,77$. Surgical repair induces damage to the membrane of muscle fibers ${ }^{78}$.

Autophagy is the process by which cells remove organelles and other cell components using lysosomal machinery to adapt to a new environment. It can be triggered by oxidized lipid accumulation, inflammation, macrophage recruitment, or endoplasmic reticulum or metabolic stress. This degradation process is crucial in muscle remodelling and atrophy. The increase in macrophage recruitment and lipid accumulation in torn rotator cuff has driven Authors to study 
Vsp34 and Beclin-1, initiation components of autophagy. Both have been found to be induced in torn rotator cuff muscles in adult rats, suggesting that its remodelling uses autophagocytic pathways ${ }^{65}$. The same Authors didn't find changes in the autophagy related transcripts Atg16L1, Atg5, Beclin-1 and Vps34 doing the same injury to older rats ${ }^{71}$. Several Authors have studied the molecular mechanisms behind the autophagy processes. Their results show that when atrophy is only preceded by tendon transection, LC3B, ATG12 and the LC3BII/LC3BI index are increased. This suggests that muscle atrophy after tendon transection, with no denervation associated is also mediated by autophagy ${ }^{73}$. Moreover, mTOR, that suppresses the autophagy initiation complex, has been shown to be decreased in rotator cuff muscle following tendon transection and increased after denervation. Therefore, autophagy may be suppressed after denervation, due to the inhibition of the activation complex by mTOR, which increases after denervation.

Rapid onset of atrophy can also be triggered by blocking the release of the synaptic vesicles with botulinum neurotoxin, or blocking of AChR with alpha bungarotoxin at the synaptic junction, which may be followed by an increased myogenic and adipogenic response 69 .

Mouse. As in rats, tenotomy also produced muscle atrophy, increased by the addition of suprascapular nerve neurotomy ${ }^{66,87}$. The changes were more severe in the infraspinatus ${ }^{66}$. Davies et al. showed that although the relative population of muscular stem cells is constant after injury, their activation is only transient ${ }^{91}$.

\section{Retraction and fibrosis}

Sheep. After tenotomy, the muscle retracts $33,34,36,39$ This phenomenon increases during the first 16 weeks after damage and there is more retraction in the tendon than in the muscle ${ }^{35,36}$. Post-injury continuous traction can recover the original muscle length ${ }^{36,38}$. This retraction can also be observed as an increase in the pennation angle, which is posteriorly recovered after continuous tensioning of the muscle ${ }^{34,36}$.

The increase in interstitial fibrous tissue is present even after immediate repair phase, remaining unaltered when the repair is done at a later time $34-36,40$. However, fibrosis improves when a continuous traction is applied to the muscle ${ }^{36}$. Mechanically, accumulation of collagen is correlated to decreased muscle elasticity ${ }^{35}$.

Rabbit. Accumulation of connective tissue is mainly localized at the endomysial and perimysial areas after tenotomy ${ }^{46}$

Rat. There is increased stiffness due to high collagen content $63,65,70,74,76,77$. Specifically, there is a decrease in the molecular weight of Titin but this was not associated to stiffer muscle fibers ${ }^{76}$. Stiffness is not only related to the size of Titin ${ }^{94}$. This phenomenon is more evident at the tendon insertion pole ${ }^{70}$. There is increased expression of the TGF- $\beta 1$ pro-fibrogenic gene $^{75,77}$. The fibrosis progressively increases regardless acute tendon repair ${ }^{81}$.

Mouse. There is increased fibrosis after tendon section, denervation or combined injury ${ }^{87}$. It would be related to upregulation of $\alpha$ SMA and Vimentin ${ }^{90}$.

\section{Fatty infiltration}

Sheep. The increase in interstitial fat after osteotomy of the infraspinatus insertion is both inter- and intrafascicular ${ }^{34-36,39}$. Two studies have assessed the effect of fatty infiltration after immediate repair ${ }^{33,40}$. By using Osmium tetroxide analysis, Coleman et al. did not observe significant increase of adipose tissue but Luan et al. found a relevant increase in adipogenic genes by RT-PCR six months after immediate repair ${ }^{33,40}$. When the tendon repair is done at 6 or 18 weeks after release, fatty infiltration decreases, but it takes longer to recover in more chronic injuries ${ }^{33}$. In the case of late repair ( 40 weeks), fatty infiltration first increases and then improves up to similar levels than those found at the time of repair ${ }^{35}$. However, it does not improve after continuous traction and repair ${ }^{36}$. At the molecular level, these changes are related to increased expression of PPARy and C/EBP $\beta$ after tendon release, and a decrease of PPARy after repair ${ }^{37}$. Fatty infiltration is mostly related to tendon than neuronal injury ${ }^{41}$.

Rabbit. Fatty infiltration is present four weeks after detachment of the supraspinatus ${ }^{43,48}$. This change is more intense in the lateral than in the medial region of the muscle and is localized within and around the muscle, and inside myocites $44,47,50,53$. Fatty infiltration does not spontaneously disappear, it even progresses with the chronicity of the lesion, and does not completely reverse after repair $44,47,48,50,53$. Fatty infiltration was not observed in partial tears ${ }^{49}$. Interestingly, fatty infiltration was also seen in a model of acute (immediate) repair, suggesting that SSP retraction is not essential for the development of fatty infiltration $^{48}$

Rat. To induce a stable fatty infiltration, both the supraspinatus and infraspinatus must be tenotomized and released to allow tendon retraction ${ }^{70,83}$. Simple supraspinatus tenotomy only produces an early transient fatty infiltration ${ }^{86}$. Fatty infiltration is more severe when suprascapular neurotomy is added $63,66,68,77,87$. As observed in rabbits, fatty infiltration is more pronounced in the musculotendinous junction at 4 weeks ${ }^{61}$.

The deposition of lipids is also present within the muscle fibers 65,66 . Fatty infiltration progresses with chronicity and is localized principally in the infraspinatus ${ }^{66}$. These changes are similar in young and adult rats ${ }^{62}$. At molecular level, PPARy and $\mathrm{C} / \mathrm{EBP} \alpha$ are increased, as well as the lipid marker perilipin-1, which accumulates earlier in the distal 
portion $61,65,66,77$. Joshi et al. found that after tenotomy with denervation there was an increase in PPARy and SREBP-1, which was associated to upregulation of the mTOR signalling ${ }^{68}$. Leptin, another marker of adipose tissue, is also upregulated 66 .

Fatty infiltration can be related to BMPs. Inhibition of BMP signalling with intraperitoneal injection of LDN193189 reduces supraspinatus fatty infiltration, as seen with Oil Red staining and decreased expression of SREBP1 ${ }^{80}$. Davies et al. showed that the fatty infiltration, associated to upregulated adipogenic pathways, appeared after rotator cuff section, but not after gastrocnemius muscle section in rats, suggesting that the rotator cuff has a differential response to lesions ${ }^{77}$.

Mouse. Also showed fatty infiltration, increased by the addition of neurotomy to tenotomy ${ }^{90,95}$. Although fatty infiltration was more intense in the infraspinatus, this process was found together with upregulation of PPAR- $\gamma$, adiponectin and perilipin $A^{66,90}$. Klopms et al. showed that the fatty tissue does not come from circulating bone marrow stem cells ${ }^{92}$. Kuenzler et al. found that this change is related to PARP-189. Lee et al. showed that fatty infiltration is mediated by FABP4, which is, itself, regulated by $\mathrm{HIF} 1^{93}$.

\section{Inflammation}

Gumucio et al., in a rat model of tenotomy without neurotomy, found macrophages in areas of fatty degeneration. Also the expression of IL-10 was decreased, while IL-6 and IL-1 1 levels were unaltered ${ }^{65}$. The same model with older rats (24 months) showed the same findings. The pro-inflammatory macrophage 1 (M1) subpopulation marker CCR7 was unchanged, but CD11b and CD68 were increased. The anti-inflammatory M2 macrophage marker, CD168 was unchanged ${ }^{71}$. This is in agreement with the facts that the process of atrophy after tenotomy without denervation seems to be autophagy and macrophages are responsible for phagocytosis in autophagy65,71,87.

When muscle tissue is damaged, an inflammatory process is triggered and it is necessary to regenerate and heal the tissue. However, it has to be perfectly regulated, because a prolonged inflammatory response can stimulate excessive tissue remodelling causing fibrosis. The M1 subpopulation of macrophages are responsible for the initial inflammatory response and the M2 subpopulation come into play in later repairing and remodelling stages ${ }^{96,97}$. However, the macrophages are responsible for the increase in RhoA expression, which is associated with the increase in TNF- $\alpha$ and TGF- $B 1$, and atrophy, fibrosis and fatty infiltration ${ }^{98}$.

\section{Muscular function}

Muscular function has also been studied in experimental models both in vitro and in vivo. In one of the earliest experimental studies, Bjorkenheim et al. showed that the section of the supraspinatus tendon in rabbits leads to changes in the contractile re- sponse with increased fatigue and muscular insufficiency after repeated stimulation, in line with the atrophy observed ${ }^{43}$. Fabis et al. described a loss of twitch tension and a decrease in the fatigue index after the detachment of the supraspinatus muscle in rabbits, that was markedly present 6 weeks after detachment and continued increasing slowly after six months ${ }^{44,45}$. In vivo, the average force of infraspinatus muscle contraction in a sheep model decreased by a $48 \%$ six weeks after tendon detachment, and $52 \%$ after 18 weeks ${ }^{14}$. An immediate repair after detachment prevented muscle force loss. A delayed 6 weeks repair of the tendon partially reverted the force decrease at 12 (22\% recovery) and 20 weeks (36\% recovery). However, a delayed repair at 18 weeks after detachment needed 30 weeks to show some improvement. Meyer et al. showed that, in sheep, tendon tears were not only related to fatty infiltration, retraction and atrophy, but also to loss of strength and contractile amplitude of muscle. The loss of muscle work correlated with the fatty infiltration ${ }^{39}$.

Rowshan et al. found that the complete section of the subscapularis tendon in rabbits induced histologic changes in the muscle, that were very similar to those observed after muscle denervation. This supports the hypothesis that nervous damage may be induced by a tendinous lesion ${ }^{52}$. However, Gayton et al. examined in detail the histology of the supraspinatus muscle of rabbits three months after tendon section, and they saw no evidence of denervation, despite that atrophy and fatty degeneration were evident ${ }^{55}$.

Mannava et al. studied in rats the effect of the tension required to repair an acute or chronic supraspinatus tendon tear, based on the amplitude of the maximal tetanic contraction and the compound motor action potential of the muscle (CMAP). They observed that chronic lesions, that required a higher tension in the repair, had lower muscle force and CMAP than acute lesions, highlighting the better functional prognosis of an early repair after injury ${ }^{64}$. Gumucio et al. studied the force production of a single rat muscle fibre 30 days after supraspinatus and infraspinatus tendon section. They observed a decrease in force production associated to an induction of fibrogenic, adipogenic, and inflammatory gene expression ${ }^{65}$. In a subsequent study, they found that the extent of degenerative changes in old rats was greater than that found in adults ${ }^{71}$. Ditsios et al. also described a marked decrease in force after supraspinatus and infraspinatus section in rats. In a detailed 3D histological study, they observed that the degeneration and the fatty infiltration were more evident near the tendon and at the dorsal side in both muscles ${ }^{70}$.

\section{Therapeutic research}

This section is summarized in Table II. Within the different pharmacological therapies, Gerber et al. first observed that in sheep, intramuscular injection of nandrolone decanoate, administered in the muscle belly of the infraspinatus, was unable to regenerate the muscle when degenerative changes are pre- 
Table II. Therapeutic studies.

\begin{tabular}{|c|c|c|c|c|}
\hline Animal & Reference & Injury & Intervention & Repair \\
\hline \multirow{3}{*}{$\frac{\stackrel{0}{\Phi}}{\stackrel{\Xi}{\infty}}$} & Gerber et al. $2012^{99}$ & $\begin{array}{l}\text { ISP osteotomy + lengthening } \\
\text { at week } 16 \text { for } 6 \text { weeks }\end{array}$ & $\begin{array}{l}\text { Nandrolone decanoate / IGF-1- } \\
\text { PLGA microsphere }\end{array}$ & W22 \\
\hline & $\begin{array}{l}\text { Gerber et al. } 2015^{100} \\
\text { Flück et al. } 2017^{101}\end{array}$ & ISP osteotomy and wrapping & $\begin{array}{l}\text { Nandrolone decanoate (injection } \\
\text { into gluteus maximus) }\end{array}$ & W16 \\
\hline & Ruoss et al. $2018^{102}$ & ISP osteotomy and wrapping & $\begin{array}{l}\text { Nandrolone decanoate (injection } \\
\text { into gluteus maximus) }\end{array}$ & W16 \\
\hline \multirow{5}{*}{$\begin{array}{l}\text { 능 } \\
\frac{0}{0} \\
\text { 밈 }\end{array}$} & Gerber et al. $2011^{103}$ & SSP release & Nandrolone decanoate & --- \\
\hline & Oh et al. $2014^{104}$ & $\begin{array}{l}\text { Subscapularis detachment and } \\
\text { wrapping }\end{array}$ & Heterologous ADSC & W6 \\
\hline & Kim et al. $2014^{105}$ & SSP detachment & ADMSC & W3 \\
\hline & Gilotra et al. $2015^{106}$ & SSP transection and wrapping & Botulinum toxin & W12 \\
\hline & Chung et al. $2016^{107}$ & SSP detachment & Simvastatin & W10 \\
\hline \multirow{7}{*}{ 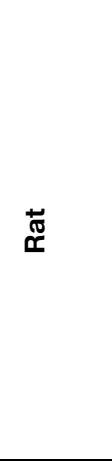 } & Oak et al. $2014^{108}$ & SSP TT and wrapping & Licofelone & W4 \\
\hline & Davis et al. $2015^{109}$ & SSP TR & Simvastatin & --- \\
\hline & Gumucio et al. $2016{ }^{110}$ & SSP TT & $\begin{array}{l}\text { Stromal vascular fraction of } \\
\text { adipose tissue }\end{array}$ & W4 \\
\hline & Wilde et al. $2016{ }^{111}$ & SSP TT and wrapping & Intraperitoneal SB203580 & D30 \\
\hline & Sevivas et al. $2016{ }^{112}$ & SSP + ISP TT & Secretome from human MSCs & --- \\
\hline & Takase et al. $2016{ }^{113}$ & SSP + ISP TT & Subacromial PRP & --- \\
\hline & Gumucio et al. 2017114 & SSP TT and wrapping & PHD inhibitor GSK1120360A & W4 \\
\hline \multirow{5}{*}{$\begin{array}{l}\stackrel{0}{0} \\
\stackrel{0}{0} \\
\Sigma\end{array}$} & Cho et al. $2015^{115}$ & SSP + ISP TR + SSN NT & Tamoxifen & --- \\
\hline & Davies et al. 2016116 & SSP + ISP TT + SSN NT & Intraperitoneal SB431542 & --- \\
\hline & 0 & & TGF- $\beta$ inhibitor & \\
\hline & Eliasberg et al. $20177^{117}$ & SSP + ISP TT or SSP + ISP TT + NT & Allogenic perivascular stem cells & --- \\
\hline & Shirasawa et al. 201795 & $\begin{array}{l}\text { Whole rotator cuff transection + SSN } \\
\mathrm{NT}+\text { humeral head resection }\end{array}$ & $\begin{array}{l}\text { Imatinib mesylate } \\
\text { (PDFGR inhibitor) }\end{array}$ & --- \\
\hline
\end{tabular}

SSP supraspinatus, ISP: infraspinatus, SSN: supraescapular nerve, TT tenotomy, TR tendon resection, NT neurotomy CLS contralateral side, SG: specific group, W: week, D: day.

ADSC adipose tissue derived stem cell, MSC mesenchimal stem cell, PRP platelet rich plasma.

sent ${ }^{99}$. The anabolic steroid administered alio loco prevented fatty infiltration, reducing functional muscle damage in rabbits and sheep ${ }^{100,101,103}$. It prevents fatty infiltration when administered after tendon release and also prevents further degenerative changes after surgical repair if administered after tendon repair, but cannot reverse it when already present. The same group showed that anabolic steroids and IGF-I, a growth factor with muscle anabolic properties, had no beneficial effect in a sheep model of muscle degeneration ${ }^{99}$. Analyzing the effect of 5-LOX, COX-1, and
COX-2 inhibition with licofelone, Oak et al. targeted the fibrogenic process of muscle injury. They observed a marked reduction in fibrosis and lipid content in supraspinatus muscles with reduced expression of several genes involved in fatty infiltration ${ }^{108}$. Cho et al. studied the effect of tamoxifen, an estrogenic agonist with anabolic effects. Although it produced decreased atrophy and endomysial inflammation, there were no significant differences in the amount of intramuscular adipocytes and lipid droplets nor in the expression of adipogenic genes ${ }^{115}$. With 
the previous observations indicating that hypercholesterolemia impairs tendon to bone regeneration, and that statins prevent fibrosis and inflammation in other diseases, Davis et al. investigated the effect in a model of rotator cuff repair in rats. They observed that simvastatin increased fiber specific force and reduced collagen content, but without significant effect on atrophy or triglyceride content. Simvastatin downregulated PPARy, C/EBP $\alpha, \mathrm{CD} 68$, eMHC, and most of the genes involved in ECM synthesis, fibrosis, and fibroblast proliferation 77,109 . Recently, Chung et al. observed that treatment with statins was beneficial in a rabbit model of fatty infiltration ${ }^{107}$. Davies et al. showed that blocking the pro-fibrotic factor TGF- $\beta$ down regulates the expression of fibrotic, adipogenic, and atrophy-related genes, reducing the number of fibro/adipogenic progenitor cells by promoting their apoptosis; thus, fibrosis, fatty infiltration, and muscle weight loss were reduced. Wilde et al. demonstrated that blocking p38 MAPK signalling, involved in the regulation of adipocyte activity, decreased the adipose and collagen content ${ }^{111}$. Hypoxia-inducible factor-1 alpha has also been shown to be positively involved in the prevention of degenerative changes after tendon injury ${ }^{114}$. More recently, Shirasawa et al. showed that the inhibition of PDGFR was able to supress the muscular fibro-fatty degeneration ${ }^{95}$.

Gilotra et al. described the damaging effects of botulinum toxin in the muscle after tendon repair confirming the previous reports that used botulinum toxin as a mechanism of injury (Tab. I) ${ }^{106}$.

After tendon detachment in rabbits, Oh et al. showed a decrease of fatty infiltration if repair was complemented with muscular injection of adipose-derived stem cells ${ }^{104}$. Similarly, Kim et al. observed that transplanted adipose-derived stem cells produced a higher expression of IGF1R and MHC ${ }^{105}$. The positive effect of stem cells was also observed by Eliasberg et al. when injecting allogenic perivascular stem cells to mice with chronic rotator cuff injury ${ }^{117}$. Other Authors have studied the effect of stromal vascular fraction cells of adipose tissue, the secretome from mesenchymal stem cells and platelet rich plasma to improve muscle recovery ${ }^{112,113}$.

\section{Discussion}

The purpose of this review was to recapitulate the most significant findings on animal models of the muscular degeneration after rotator cuff injury, to get a better understanding of one of most common muscle pathologies in orthopaedic patients. Most of the reviewed works are focussed on the muscular atrophy of the rotator cuff muscles after tendon injury, mainly characterized by changes in fiber type composition, with muscles accumulating more type IIb fibers. This fiber shift from type I towards type II suggests that the muscles of rotator cuff change from an endurance muscle (predominant type I muscular fibers) to a resistance muscle (predominant type Ilb fibers) after tendon injury, since type II fibers are strength training, glycolytic fibers, unable to maintain sustained contraction ${ }^{118}$.

Among the different animal models of tendon tears, dysregulation of the principal proteolytic systems implicated in protein quality control, namely, the autophagy-lysosomal system and the ubiquitin-proteasome system, leads to atrophy. Ubiquitin-proteasome is the main mechanism in animal models that included neurotomy, while autophagy-lysosomal system seems to be predominant in those using simple tendon section or resection $67,68,119,120$. In human, Schmutz et al. found that CAPN1, APN1, UBE2B, and $U B E 3 A$ genes were up-regulated after tendon injury, supporting proteolysis as the main process leading to muscular atrophy ${ }^{22}$. However, the relevance of neuropathy is still under discussion in the clinical field and the mechanisms leading to atrophy need to be profoundly explored. Autophagy-lysosomal and ubiquitin-proteasome systems are connected upstream, as they are both promoted by FOXO 1/3. In addition, AKT/PKB signalling can block the activity of FOXO $1 / 3$ and autophagy through the activation of mTOR. Thus, one possible explanation for the differences between tenotomy and neurotomy is that in simple tenotomy decreases anabolism and increases autophagy as a consequence of mTOR pathway down-regulation to avoid cellular apoptosis, which in turn is congruent with the role of mTOR as an autophagy inhibitor ${ }^{121}$. In the case of neurotomy, both the AKT/mTOR (protein synthesis) and ubiquitin/proteasome (MurF1, MAFbx) pathways are up-regulated, and thus autophagy is inhibited by $\operatorname{mTOR}^{67}$. This scenario may explain why autophagy is the main responsible for muscle atrophy after tenotomy, while ubiquitin/proteasome system is the most common after tenotomy with denervation ${ }^{73}$. However, other possibility to explain these differences could be related to the age of the animals, since aging is associated with perturbed proteostasis. Gumucio et al. showed activation of autophagy in a 6 month-old-rat model of tenotomy without SSN section, but not in 24 months aged rats ${ }^{65,71}$.

Muscular atrophy means that the coordinated muscle repair response after tendon injury ${ }^{122}$ is lost, and the function of different cell populations within the skeletal muscle is completely impaired. Immediately after tendon injury, muscular degeneration triggers accumulation and activation of the inflammatory cells, which should activate the quiescent satellite cells to start muscle repair. However, the increase of pro-inflammatory M1 macrophages is not switched off and followed by accumulation of anti-inflammatory M2 macrophages. This excess of the inflammatory response worsen the injury, stimulating a disproportionate tissue remodelling causing fibrosis. The mechanisms underlying fibrosis in rotator cuff injuries are not well understood, but the pathological prevalence of fibroblasts around and within the muscle after tendon injury has linked poor muscle function to increased expression of fibrotic markers ${ }^{90}$. Similarly, the presence of adult adipose cells, which is excep- 
tional in healthy muscles, notably increases after tendon injury, contributing to muscle repair failure. Fatty infiltration, normally associated to an upregulation of adipogenic genes $66,68,71$, is mainly dependent on tendon retraction, progresses after tendon injury and becomes not reversible with tendon repair. Nevertheless, tendon retraction is not indispensable for the development of fatty infiltration, as it is also present after immediate tendon repair ${ }^{40,48}$. Fat infiltration strongly correlates with poor clinical outcomes and success rates of rotator cuff repair, because further to impair muscle function, there is a level of fat infiltration that is irreversible even following repair. Inadequate inflammatory response, accumulation of fibrotic tissue and fatty infiltration after tendon injury exceed the regenerative capacity of the satellite cells, as it has been demonstrated in human muscles with full thickness tendon tear $7,8,12,13$. However, an increased satellite cell population, with less replicative potential, is described in tendons with partial tears ${ }^{7,8,12}$. Similarly, in sheep and rat experimental models, there is upregulation of Myf5 when neurotomy of the SSN is added to tenotomy ${ }^{37,66}$. Since $\mathrm{Myf5}^{+}$satellite cells are committed to differentiation rather to maintain the reservoir of the satellite cells ${ }^{123}$, we may speculate that loss of asymmetric satellite cell divisions is the cause of stem cell depletion in the rotator cuff, contributing to the development of muscular atrophy ${ }^{124}$. All these evidences suggest a cellular relation between inflammation, fibrosis and fatty infiltration after tendon injury. Within the normal interfibrillar component of the skeletal muscle there are quiescent cells, which do not derive from myogenic progenitors and are unable to differentiate into muscle cells ${ }^{125,126}$. Because these cells have the potential to differentiate into fibrous and adipose lineages upon activation ${ }^{126}$, they are called fibro-adipogenic progenitors (FAPs). FAP cells promote muscle repair after injury through interacting with the satellite cells ${ }^{126,127}$ and, interestingly, FAP cells may be regulated by immune cells. Infiltrating monocytes induce the apoptosis of FAPs as they produce TNF, while macrophages prevent FAPs death and induce their differentiation by expressing TGF- $\beta 1^{116,127-130}$. Recently, these FAP cells have been identified in the muscles of the rotator cuff ${ }^{116,9,125}$, supporting that they generate the fibrous and adipose tissues after tendon injury ${ }^{126,133}$. Expression of platelet-derived growth factor receptor alpha (PDGFR $\alpha$ ), characteristic of the FAPs cells ${ }^{129,131}$, is highly increased in rat muscles of tendon tears, correlating with high fibrosis and fatty infiltration 65 , while inhibition of PDGFR ${ }^{+}$cells in tendon injury mouse models prevents muscle fatty infiltration ${ }^{95}$. These findings demonstrate that fibrosis and adipocyte accumulation in rotator cuff muscles after damage mainly comes from PDGFR $^{+}$mesenchymal cells, the FAPs $^{90}$. Although these evidences rise the possibility that fibrosis and fatty infiltration leads to muscular atrophy, some investigators have suggested these are different cellular processes. Liu et al. showed that blocking BMP signalling results in increased muscle atrophy and decreased fatty infiltration in rotator cuff ${ }^{80}$, and clinically, atrophy comes first, followed later by fatty infiltration.

Different therapeutic strategies such as pharmacological and cell therapy approaches have been developed to counteract rotator cuff muscles after tendon tears by reducing fatty infiltration and fibrogenic process or increasing the regenerative response of the satellite cells and muscular mass. However, they are no effective treatment for these muscle pathologies. The identification of FAPs as the major cellular sources of rotator cuff muscles fibrosis and fatty infiltration, with the potential to drive satellite cell to promote myogenesis opens new perspective for developing cellular targeted treatments for these diseases. The limitations of this study are derived of the heterogeneity of the different studies in the field. In consequence, although there are multiple mechanisms with potential as targets for efficient therapies in the treatment of tendon tears and recovery of muscular injuries, their translation to clinical settings seems still far away.

\section{Conclusion}

Muscular degeneration after tendon injury is still an unsolved problem. There have been established animal models in sheep, rabbit, rat and mouse to model human disease and assess the effect of different therapeutic strategies. A key factor of these animal models of tendon injury is whether they include or not the resection of the suprascapular nerve, because the type and mechanism of muscle atrophy is different. In recent years there are more studies focusing on the cellular origin of the fibrous and adipose tissue, since they are hallmark of muscle degeneration and prevent muscle repair.

Clarification of the molecular and cellular interrelations of the muscular phenomena, - atrophy, fibrosis, fatty infiltration and inflammation - and how they affect satellite cell function, could make more targeted therapies possible.

\section{Conflict of interest}

No other relationships/conditions/circumstances that present potential conflict of interest.

\section{Funding}

Not applicable.

\section{References}

1. Oliva F, Piccirilli E, Bossa M, et al. I.S.Mu.L.T - Rotator Cuff Tears Guidelines. Muscles Ligaments Tendons J. 2015;5: 227-263. 
2. Moher D, Liberati A, Tetzlaff J, Altman DG, the PRISMA Group. Preferred reporting items for systematic reviews and meta-analyses: the PRISMA statement. J Clin Epidemiol. 2009;62:1006-1012.

3. Padulo J, Oliva F, Frizziero A, Maffulli N. Muscles, Ligaments and Tendons Journal - Basic principles and recommendations in clinical and field science research: 2016 update. MLTJ. 2016;6(1):1-5.

4. Irlenbusch U, Gansen HK. Muscle biopsy investigations on neuromuscular insufficiency of the rotator cuff: a contribution to the functional impingement of the shoulder joint. J Shoulder EIbow Surg. 2003;12:422-426.

5. Gigliotti D, Xu MC, Davidson MJ, Macdonald PB, Leiter JR, Anderson JE. Fibrosis, low vascularity, and fewer slow fibers after rotator-cuff injury. Muscle Nerve. 2017;55(5):715-726.

6. Steinbacher P, Tauber M, Kogler S, Stoiber W, Resch H, Sanger AM. Effects of rotator cuff ruptures on the cellular and intracellular composition of the human supraspinatus muscle. Tissue Cell. 2010;42:37-41.

7. Gigliotti D, Leiter JR, Macek B, Davidson MJ, MacDonald PB, Anderson JE. Atrophy, inducible satellite cell activation, and possible denervation of supraspinatus muscle in injured human rotator-cuff muscle. Am J Physiol Cell Physiol. 2015;309: C383-391.

8. Lundgreen $\mathrm{K}$, Lian OB, Engebretsen L, Scott A. Lower muscle regenerative potential in full-thickness supraspinatus tears compared to partial-thickness tears. Acta Orthop. 2013;84: 565-570.

9. Fuchs B, Zumstein M, Regenfelder F, et al. Upregulation of alpha-skeletal muscle actin and myosin heavy polypeptide gene products in degenerating rotator cuff muscles. J Orthop Res. 2008;26:1007-1011.

10. Mauro A. Satellite cell of skeletal muscle fibers. J Biophys Biochem Cytol. 1961;9:493-495.

11. Charge SB, Rudnicki MA. Cellular and molecular regulation of muscle regeneration. Physiol Rev. 2004;84:209-238.

12. Meyer GA, Farris AL, Sato E, et al. Muscle progenitor cell regenerative capacity in the torn rotator cuff. J Orthop Res. 2015;33:421-429.

13. Thomas KA, Gibbons MC, Lane JG, Singh A, Ward SR, Engler AJ. Rotator cuff tear state modulates self-renewal and differentiation capacity of human skeletal muscle progenitor cells. J Orthop Res. 2017;35:1816-1823.

14. Choo A, McCarthy M, Pichika R, et al. Muscle gene expression patterns in human rotator cuff pathology. J Bone Joint Surg Am. 2014;96:1558-1565.

15. Silldorff MD, Choo AD, Choi AJ, et al. Effect of supraspinatus tendon injury on supraspinatus and infraspinatus muscle passive tension and associated biochemistry. J Bone Joint Surg Am. 2014;96:e175.

16. Raz Y, Henseler JF, Kolk A, et al. Molecular signatures of ageassociated chronic degeneration of shoulder muscles. Oncotarget. 2016;7:8513-8523.

17. Shah SA, Kormpakis I, Cavinatto L, Killian ML, Thomopoulos S, Galatz LM. Rotator cuff muscle degeneration and tear severity related to myogenic, adipogenic, and atrophy genes in human muscle. J Orthop Res. 2017;35:2808-2814.

18. Hersche $\mathrm{O}$, Gerber $\mathrm{C}$. Passive tension in the supraspinatus musculotendinous unit after long-standing rupture of its tendon: a preliminary report. J Shoulder Elbow Surg. 1998;7:393396.

19. Gibbons MC, Singh A, Anakwenze O, et al. Histological Evidence of Muscle Degeneration in Advanced Human Rotator Cuff Disease. J Bone Joint Surg Am. 2017;99:190-199.

20. Bonaldo P, Sandri M. Cellular and molecular mechanisms of muscle atrophy. Dis Model Mech 2013; 6: 25-39.

21. Milan G, Romanello V, Pescatore F, et al. Regulation of autophagy and the ubiquitin-proteasome system by the FoxO transcriptional network during muscle atrophy. Nat Commun. 2015;6:6670.

22. Schmutz S, Fuchs T, Regenfelder F, Steinmann P, Zumstein $M$, Fuchs B. Expression of atrophy mRNA relates to tendon tear size in supraspinatus muscle. Clin Orthop Relat Res. 2009;467:457-464.

23. Warner JP, Krushell RJ, Masquelet A, Gerber C. Anatomy and relationships of the suprascapular nerve: anatomical constraints to mobilization of the supraspinatus and infraspinatus muscles in the management of massive rotator-cuff tears. $J$ Bone Joint Surg Am. 1992;74:36-45.

24. Goutallier D, Postel JM, Van Driessche S, Voisin MC. [Histological lesions of supraspinatus tendons in full thickness tears of the rotator cuff]. Rev Chir Orthop Reparatrice Appar Mot. 2005;91:109-113.

25. Mallon WJ, Wilson RJ, Basamania CJ. The association of suprascapular neuropathy with massive rotator cuff tears: a preliminary report. J Shoulder Elbow Surg. 2006;15:395-398.

26. Vad VB, Southern D, Warren RF, Altchek DW, Dines D. Prevalence of peripheral neurologic injuries in rotator cuff tears with atrophy. J Shoulder Elbow Surg. 2003;12:333-336.

27. Collin $\mathrm{P}$, Treseder $\mathrm{T}$, Ladermann $\mathrm{A}$, et al. Neuropathy of the suprascapular nerve and massive rotator cuff tears: a prospective electromyographic study. J Shoulder Elbow Surg. 2014 23:28-34.

28. Shi LL, Boykin RE, Lin A, Warner JJ. Association of suprascapular neuropathy with rotator cuff tendon tears and fatty degeneration. J Shoulder Elbow Surg. 2014;23:339-346.

29. Albritton MJ, Graham RD, Richards RS, 2nd, Basamania CJ. An anatomic study of the effects on the suprascapular nerve due to retraction of the supraspinatus muscle after a rotator cuff tear. J Shoulder Elbow Surg. 2003;12:497-500.

30. Greiner A, Golser K, Wambacher M, Kralinger F, Sperner G. The course of the suprascapular nerve in the supraspinatus fossa and its vulnerability in muscle advancement. J Shoulder Elbow Surg. 2003;12:256-259.

31. Beeler S, Ek ET, Gerber C. A comparative analysis of fatty infiltration and muscle atrophy in patients with chronic rotator cuff tears and suprascapular neuropathy. J Shoulder Elbow Surg. 2013;22:1537-1546.

32. Boykin RE, Friedman DJ, Zimmer ZR, Oaklander AL, Higgins LD, Warner JJ. Suprascapular neuropathy in a shoulder referral practice. J Shoulder Elbow Surg. 2011;20:983-988.

33. Coleman SH, Fealy S, Ehteshami JR, et al. Chronic rotator cuff injury and repair model in sheep. J Bone Joint Surg Am. 2003;85-A:2391-2402.

34. Meyer DC, Hoppeler H, von Rechenberg B, Gerber C. A pathomechanical concept explains muscle loss and fatty muscular changes following surgical tendon release. J Orthop Res. 2004;22:1004-1007.

35. Gerber C, Meyer DC, Schneeberger AG, Hoppeler H, von Rechenberg B. Effect of tendon release and delayed repair on the structure of the muscles of the rotator cuff: an experimental study in sheep. J Bone Joint Surg Am. 2004;86-A:1973-1982.

36. Gerber C, Meyer DC, Frey E, et al. Neer Award 2007: Reversion of structural muscle changes caused by chronic rotator cuff tears using continuous musculotendinous traction. An experimental study in sheep. J Shoulder Elbow Surg. 2009;18: 163-171.

37. Frey E, Regenfelder F, Sussmann P, et al. Adipogenic and myogenic gene expression in rotator cuff muscle of the sheep after tendon tear. J Orthop Res. 2009;27:504-509.

38. Zumstein MA, Frey E, von Rechenberg B, Frigg R, Gerber C, Meyer DC. Device for lengthening of a musculotendinous unit by direct continuous traction in the sheep. BMC Vet Res. 2012;8:50.

39. Meyer DC, Gerber C, Von Rechenberg B, Wirth SH, Farshad $M$. Amplitude and strength of muscle contraction are educed in 
experimental tears of the rotator cuff. Am J Sports Med. 2011;39:1456-1461.

40. Luan T, Liu X, Easley JT, Ravishankar B, Puttlitz C, Feeley BT Muscle atrophy and fatty infiltration after an acute rotator cuff repair in a sheep model. Muscles Ligaments Tendons $\mathrm{J}$. 2015;5:106-112.

41. Gerber C, Meyer DC, Fluck M, et al. Muscle Degeneration Associated With Rotator Cuff Tendon Release and/or Denervation in Sheep. Am J Sports Med. 2017;45:651-658.

42. Safran O, Derwin KA, Powell K, lannotti JP. Changes in rotator cuff muscle volume, fat content, and passive mechanics af ter chronic detachment in a canine model. J Bone Joint Surg Am. 2005;87:2662-2670.

43. Bjorkenheim JM. Structure and function of the rabbit's supraspinatus muscle after resection of its tendon. Acta Orthop Scand. 1989;60:461-463.

44. Fabis J, Kordek P, Bogucki A, Synder M, Kolczynska H. Function of the rabbit supraspinatus muscle after detachment of its tendon from the greater tubercle. Observations up to 6 months. Acta Orthop Scand. 1998;69:570-574.

45. Fabis J, Kordek P, Bogucki A, Mazanowska-Gajdowicz J. Function of the rabbit supraspinatus muscle after large detachment of its tendon: 6-week, 3-month, and 6-month observation. J Shoulder Elbow Surg. 2000;9:211-216.

46. Fabis J, Danilewicz M, Omulecka A. Rabbit supraspinatus tendon detachment: effects of size and time after tenotomy on morphometric changes in the muscle. Acta Orthop Scand. 2001;72:282-286.

47. Matsumoto F, Uhthoff HK, Trudel G, Loehr JF. Delayed tendon reattachment does not reverse atrophy and fat accumulation of the supraspinatus-an experimental study in rabbits. J Orthop Res. 2002;20:357-363.

48. Uhthoff HK, Matsumoto F, Trudel G, Himori K. Early reattachment does not reverse atrophy and fat accumulation of the supraspinatus - an experimental study in rabbits. J Orthop Res. 2003;21:386-392.

49. Gupta R, Lee TQ. Contributions of the different rabbit models to our understanding of rotator cuff pathology. J Shoulder Elbow Surg. 2007;16:S149-157.

50. Rubino LJ, Stills HF, Jr., Sprott DC, Crosby LA. Fatty infiltration of the torn rotator cuff worsens over time in a rabbit model. Arthroscopy. 2007;23:717-722.

51. Rubino LJ, Sprott DC, Stills HF, Jr., Crosby LA. Fatty infiltration does not progress after rotator cuff repair in a rabbit model. Arthroscopy. 2008;24:936-940.

52. Rowshan K, Hadley S, Pham K, Caiozzo V, Lee TQ, Gupta R Development of fatty atrophy after neurologic and rotator cuff injuries in an animal model of rotator cuff pathology. J Bone Joint Surg Am. 2010;92:2270-2278.

53. Trudel G, Ryan SE, Rakhra K, Uhthoff HK. Extra- and intramuscular fat accumulation early after rabbit supraspinatus tendon division: depiction with CT. Radiology. 2010;255:434-441.

54. Trudel G, Ryan SE, Rakhra K, Uhthoff HK. Muscle tissue atrophy, extramuscular and intramuscular fat accumulation, and fat gradient after delayed repair of the supraspinatus tendon: A comparative study in the rabbit. J Orthop Res. 2012;30:781786.

55. Gayton JC, Rubino LJ, Rich MM, Stouffer MH, Wang Q, Boivin GP. Rabbit supraspinatus motor endplates are unaffected by a rotator cuff tear. J Orthop Res. 2013;31:99-104.

56. Uhthoff HK, Coletta E, Trudel G. Intramuscular fat accumulation and muscle atrophy in the absence of muscle retraction. Bone Joint Res. 2014;3:117-122.

57. Fabis J, Danilewicz M, Zwierzchowski JT, Niedzielski K. Atrophy of type I and II muscle fibers is reversible in the case of grade $>2$ fatty degeneration of the supraspinatus muscle: an experimental study in rabbits. J Shoulder Elbow Surg. 2016;25:487-492.
58. Barton ER, Gimbel JA, Williams GR, Soslowsky LJ. Rat supraspinatus muscle atrophy after tendon detachment. J Orthop Res. 2005;23:259-265.

59. Ward SR, Sarver JJ, Eng CM, et al. Plasticity of muscle architecture after supraspinatus tears. J Orthop Sports Phys Ther. 2010;40:729-735.

60. Buchmann S, Walz L, Sandmann GH, et al. Rotator cuff changes in a full thickness tear rat model: verification of the optimal time interval until reconstruction for comparison to the healing process of chronic lesions in humans. Arch Orthop Trauma Surg. 2011;131:429-435.

61. Itoigawa Y, Kishimoto KN, Sano H, Kaneko K, Itoi E. Molecular mechanism of fatty degeneration in rotator cuff muscle with tendon rupture. J Orthop Res. 2011;29:861-866.

62. Farshad M, Wurgler-Hauri CC, Kohler T, Gerber C, Rothenfluh DA. Effect of age on fatty infiltration of supraspinatus muscle after experimental tendon release in rats. BMC Res Notes. 2011;4:530.

63. Liu X, Manzano G, Kim HT, Feeley BT. A rat model of massive rotator cuff tears. J Orthop Res. 2011;29:588-595.

64. Mannava S, Plate JF, Whitlock PW, et al. Evaluation of in vivo rotator cuff muscle function after acute and chronic detachment of the supraspinatus tendon: an experimental study in an animal model. J Bone Joint Surg Am. 2011;93:1702-1711.

65. Gumucio JP, Davis ME, Bradley JR, et al. Rotator cuff tear reduces muscle fiber specific force production and induces macrophage accumulation and autophagy. J Orthop Res. 2012;30:1963-1970.

66. Kim HM, Galatz LM, Lim C, Havlioglu N, Thomopoulos S. The effect of tear size and nerve injury on rotator cuff muscle fatty degeneration in a rodent animal model. J Shoulder Elbow Surg. 2012;21:847-858.

67. Liu X, Joshi SK, Samagh SP, et al. Evaluation of Akt/mTOR activity in muscle atrophy after rotator cuff tears in a rat model. J Orthop Res. 2012;30:1440-1446.

68. Joshi SK, Liu X, Samagh SP, et al. mTOR regulates fatty infiltration through SREBP-1 and PPARgamma after a combined massive rotator cuff tear and suprascapular nerve injury in rats. J Orthop Res. 2013;31:724-730.

69. Killian ML, Lim CT, Thomopoulos S, Charlton N, Kim HM, Galatz LM. The effect of unloading on gene expression of healthy and injured rotator cuffs. J Orthop Res. 2013;31:12401248.

70. Ditsios K, Boutsiadis A, Kapoukranidou D, et al. Chronic massive rotator cuff tear in rats: in vivo evaluation of muscle force and three-dimensional histologic analysis. J Shoulder Elbow Surg. 2014;23:1822-1830.

71. Gumucio JP, Korn MA, Saripalli AL, et al. Aging-associated exacerbation in fatty degeneration and infiltration after rotator cuff tear. J Shoulder Elbow Surg. 2014;23:99-108.

72. Ichinose T, Lesmana R, Yamamoto A, et al. Possible involvement of IGF-1 signaling on compensatory growth of the infraspinatus muscle induced by the supraspinatus tendon detachment of rat shoulder. Physiol Rep. 2014;2:e00197.

73. Joshi SK, Kim HT, Feeley BT, Liu X. Differential ubiquitin-proteasome and autophagy signaling following rotator cuff tears and suprascapular nerve injury. J Orthop Res. 2014;32:138144.

74. Killian ML, Cavinatto L, Shah SA, et al. The effects of chronic unloading and gap formation on tendon-to-bone healing in a rat model of massive rotator cuff tears. J Orthop Res. 2014 32:439-447.

75. Liu X, Joshi SK, Ravishankar B, Laron D, Kim HT, Feeley BT. Upregulation of transforming growth factor-beta signaling in a rat model of rotator cuff tears. J Shoulder Elbow Surg. 2014;23:1709-1716.

76. Sato EJ, Killian ML, Choi AJ, et al. Skeletal muscle fibrosis and stiffness increase after rotator cuff tendon injury and neuro- 
muscular compromise in a rat model. J Orthop Res. 2014;32: 1111-1116.

77. Davies MR, Ravishankar B, Laron D, Kim HT, Liu X, Feeley BT. Rat rotator cuff muscle responds differently from hindlimb muscle to a combined tendon-nerve injury. J Orthop Res. 2015;33:1046-1053.

78. Davis ME, Stafford PL, Jergenson MJ, Bedi A, Mendias CL. Muscle fibers are injured at the time of acute and chronic rotator cuff repair. Clin Orthop Relat Res. 2015;473:226-232.

79. Killian ML, Cavinatto LM, Ward SR, Havlioglu N, Thomopoulos S, Galatz LM. Chronic Degeneration Leads to Poor Healing of Repaired Massive Rotator Cuff Tears in Rats. Am J Sports Med. 2015;43:2401-2410.

80. Liu X, Joshi S, Ravishankar B, Laron D, Kim HT, Feeley BT. Bone morphogenetic protein signaling in rotator cuff muscle atrophy and fatty infiltration. Muscles Ligaments Tendons $\mathrm{J}$. 2015;5:113-119.

81. Melamed E, Beutel BG, Robinson D. Enhancement of acute tendon repair using chitosan matrix. Am J Orthop (Belle Mead NJ). 2015;44:212-216.

82. Sahin E, Kalem M, Zehir S, Songur M, Demirtas M. Effect of intramuscular botulinum toxin-A in a rat rotator cuff repair model: an experimental study. Acta Orthop Traumatol Turc. 2015;49: 447-452.

83. Sevivas N, Serra SC, Portugal R, et al. Animal model for chronic massive rotator cuff tear: behavioural and histologic analysis. Knee Surg Sports Traumatol Arthrosc. 2015;23:608-618.

84. Davies MR, Lee L, Feeley BT, Kim HT, Liu X. Lysophosphatidic acid-induced RhoA signaling and prolonged macrophage infiltration worsens fibrosis and fatty infiltration following rotator cuff tears. J Orthop Res. 2017;35:1539-1547.

85. Hashimoto E, Ochiai N, Kenmoku T, et al. Macroscopic and histologic evaluation of a rat model of chronic rotator cuff tear. J Shoulder Elbow Surg. 2016;25:2025-2033.

86. Thangarajah T, Henshaw F, Sanghani-Kerai A, Lambert SM, Pendegrass CJ, Blunn GW. Supraspinatus detachment causes musculotendinous degeneration and a reduction in bone mineral density at the enthesis in a rat model of chronic rotator cuff degeneration. Shoulder Elbow. 2017;9:178-187.

87. Liu X, Laron D, Natsuhara K, Manzano G, Kim HT, Feeley BT. A mouse model of massive rotator cuff tears. J Bone Joint Surg Am. 2012;94:e41.

88. Samagh SP, Kramer EJ, Melkus G, et al. MRI quantification of fatty infiltration and muscle atrophy in a mouse model of rotator cuff tears. J Orthop Res. 2013;31:421-426.

89. Kuenzler MB, Nuss K, Karol A, et al. Neer Award 2016: reduced muscle degeneration and decreased fatty infiltration after rotator cuff tear in a poly(ADP-ribose) polymerase 1 (PARP-1) knock-out mouse model. J Shoulder Elbow Surg. 2017;26:733-744.

90. Liu X, Ning AY, Chang NC, et al. Investigating the cellular origin of rotator cuff muscle fatty infiltration and fibrosis after injury. Muscles Ligaments Tendons J. 2016;6:6-15.

91. Davies MR, Garcia S, Tamaki S, et al. Muscle Stem Cell Activation in a Mouse Model of Rotator Cuff Injury. J Orthop Res. 2017. Electronic publication ahead of print.

92. Klomps LV, Zomorodi N, Kim HM. Role of transplanted bone marrow cells in development of rotator cuff muscle fatty degeneration in mice. J Shoulder Elbow Surg. 2017;26:21772186.

93. Lee YS, Kim JY, Oh KS, Chung SW. Fatty acid-binding protein 4 regulates fatty infiltration after rotator cuff tear by hypoxia-inducible factor 1 in mice. J Cachexia Sarcopenia Muscle. 2017;8:839-850.

94. Kruger M, Kotter S. Titin, a Central Mediator for Hypertrophic Signaling, Exercise-Induced Mechanosignaling and Skeletal Muscle Remodeling. Front Physiol. 2016;7:76.

95. Shirasawa H, Matsumura N, Shimoda M, et al. Inhibition of
PDGFR signaling prevents muscular fatty infiltration after rotator cuff tear in mice. Sci Rep. 2017;7:41552.

96. Rigamonti E, Zordan P, Sciorati C, Rovere-Querini P, Brunelli $\mathrm{S}$. Macrophage plasticity in skeletal muscle repair. Biomed Res Int. 2014;2014:560629.

97. Saclier M, Cuvellier S, Magnan M, Mounier R, Chazaud B. Monocyte/macrophage interactions with myogenic precursor cells during skeletal muscle regeneration. FEBS J. 2013;280: 4118-4130.

98. Davies MR, Lee L, Feeley BT, Kim HT, Liu X. Lysophosphatidic acid-induced RhoA signaling and prolonged macrophage infiltration worsens fibrosis and fatty infiltration following rotator cuff tears. J Orthop Res. 2017;35:1539-1547.

99. Gerber C, Meyer DC, Von Rechenberg B, Hoppeler H, Frigg $\mathrm{R}$, Farshad M. Rotator cuff muscles lose responsiveness to anabolic steroids after tendon tear and musculotendinous retraction: an experimental study in sheep. Am J Sports Med. 2012;40:2454-2461.

100. Gerber C, Meyer DC, Fluck M, Benn MC, von Rechenberg B, Wieser K. Anabolic Steroids Reduce Muscle Degeneration Associated With Rotator Cuff Tendon Release in Sheep. Am J Sports Med. 2015;43:2393-2400.

101. Fluck M, Ruoss S, Mohl CB, et al. Genomic and lipidomic actions of nandrolone on detached rotator cuff muscle in sheep. J Steroid Biochem Mol Biol. 2017;165:382-395.

102. Ruoss S, Mohl CB, Benn MC, et al. Costamere protein expression and tissue composition of rotator cuff muscle after tendon release in sheep. J Orthop Res. 2018;36:272-281

103. Gerber C, Meyer DC, Nuss KM, Farshad M. Anabolic steroids reduce muscle damage caused by rotator cuff tendon release in an experimental study in rabbits. J Bone Joint Surg Am. 2011;93:2189-2195.

104. Oh JH, Chung SW, Kim SH, Chung JY, Kim JY. 2013 Neer Award: Effect of the adipose-derived stem cell for the improvement of fatty degeneration and rotator cuff healing in rabbit model. J Shoulder Elbow Surg. 2014;23:445-455.

105. Kim SH, Chung SW, Oh JH. Expression of insulin-like growth factor type 1 receptor and myosin heavy chain in rabbit's rotator cuff muscle after injection of adipose-derived stem cell. Knee Surg Sports Traumatol Arthrosc. 2014;22:2867-2873.

106. Gilotra M, Nguyen T, Christian M, Davis D, Henn RF, 3rd, Hasan SA. Botulinum toxin is detrimental to repair of a chronic rotator cuff tear in a rabbit model. J Orthop Res. 2015;33:11521157.

107. Chung SW, Park H, Kwon J, Choe GY, Kim SH, Oh JH. Effect of Hypercholesterolemia on Fatty Infiltration and Quality of Tendon-to-Bone Healing in a Rabbit Model of a Chronic Rotator Cuff Tear: Electrophysiological, Biomechanical, Histological Analyses. Am J Sports Med. 2016;44:1153-1164.

108. Oak NR, Gumucio JP, Flood MD, et al. Inhibition of 5-LOX, COX-1, COX-2 increases tendon healing and reduces muscle fibrosis and lipid accumulation after rotator cuff repair. Am J Sports Med. 2014;42:2860-2868.

109. Davis ME, Korn MA, Gumucio JP, et al. Simvastatin reduces fibrosis and protects against muscle weakness after massive rotator cuff tear. J Shoulder Elbow Surg. 2015;24:280-287.

110. Gumucio JP, Flood MD, Roche SM, et al. Stromal vascular stem cell treatment decreases muscle fibrosis following chronic rotator cuff tear. Int Orthop. 2016;40:759-764.

111. Wilde JM, Gumucio JP, Grekin JA, et al. Inhibition of p38 mitogen-activated protein kinase signaling reduces fibrosis and lipid accumulation after rotator cuff repair. J Shoulder Elbow Surg. 2016;25:1501-1508.

112. Sevivas N, Teixeira FG, Portugal R, et al. Mesenchymal Stem Cell Secretome: A Potential Tool for the Prevention of Muscle Degenerative Changes Associated With Chronic Rotator Cuff Tears. Am J Sports Med. 2016. Electronic publication ahead of print. 
113. Takase $F$, Inui A, Mifune $Y$, et al. The effect of platelet-rich plasma on degeneration change of rotator cuff muscles: In vitro and in vivo evaluations. J Orthop Res. 2016;35:1806-1815.

114. Gumucio JP, Flood MD, Bedi A, Kramer HF, Russell AJ, Mendias CL. Inhibition of prolyl 4-hydroxylase decreases muscle fibrosis following chronic rotator cuff tear. Bone Joint Res. 2017;6:57-65.

115. Cho E, Zhang Y, Pruznak A, Kim HM. Effect of tamoxifen on fatty degeneration and atrophy of rotator cuff muscles in chronic rotator cuff tear: An animal model study. J Orthop Res. 2015;33:1846-1853.

116. Davies MR, Liu X, Lee L, et al. TGF-beta Small Molecule Inhibitor SB431542 Reduces Rotator Cuff Muscle Fibrosis and Fatty Infiltration By Promoting Fibro/Adipogenic Progenitor Apoptosis. PLoS One. 2016;11:e0155486.

117. Eliasberg CD, Dar A, Jensen AR, et al. Perivascular Stem Cells Diminish Muscle Atrophy Following Massive Rotator Cuff Tears in a Small Animal Model. J Bone Joint Surg Am. 2017;99:331-341.

118. Schiaffino S, Reggiani C. Fiber types in mammalian skeletal muscles. Physiol Rev. 2011;91:1447-1531.

119. Laplante M, Sabatini DM. mTOR signaling in growth control and disease. Cell. 2012;149:274-293.

120. Morita M, Gravel SP, Hulea L, et al. mTOR coordinates protein synthesis, mitochondrial activity and proliferation. Cell Cycle. 2015;14:473-480.

121. Mizushima N, Komatsu M. Autophagy: renovation of cells and tissues. Cell. 2011;147:728-741.

122. Almeida CF, Fernandes SA, Ribeiro Junior AF, Keith Okamoto O, Vainzof M. Muscle Satellite Cells: Exploring the Basic Bi- ology to Rule Them. Stem Cells Int. 2016;2016:1078686.

123. Kuang S, Kuroda K, Le Grand F, Rudnicki MA. Asymmetric self-renewal and commitment of satellite stem cells in muscle. Cell. 2007;129:999-1010.

124. Snijders T, Nederveen JP, McKay BR, et al. Satellite cells in human skeletal muscle plasticity. Front Physiol. 2015;6:283.

125. Uezumi A, Fukada S, Yamamoto N, et al. Identification and characterization of PDGFRalpha+ mesenchymal progenitors in human skeletal muscle. Cell Death Dis. 2014;5:e1186.

126. Uezumi A, Ikemoto-Uezumi M, Tsuchida K. Roles of nonmyogenic mesenchymal progenitors in pathogenesis and regeneration of skeletal muscle. Front Physiol. 2014;5:68.

127. Joe AW, Yi L, Natarajan A, et al. Muscle injury activates resident fibro/adipogenic progenitors that facilitate myogenesis. Nat Cell Biol. 2010;12:153-163.

128. Uezumi A, Fukada S, Yamamoto N, Takeda S, Tsuchida K. Mesenchymal progenitors distinct from satellite cells contribute to ectopic fat cell formation in skeletal muscle. Nat Cell Biol. 2010;12:143-152.

129. Uezumi A, Ito $T$, Morikawa $D$, et al. Fibrosis and adipogenesis originate from a common mesenchymal progenitor in skeletal muscle. J Cell Sci. 2011;124:3654-3664.

130. Lemos DR, Babaeijandaghi F, Low M,, et al. Nilotinib reduces muscle fibrosis in chronic muscle injury by promoting TNF-mediated apoptosis of fibro/adipogenic progenitors. Nat Med. 2015;21:786-794.

131. Mueller AA, van Velthoven CT, Fukumoto KD, Cheung TH, Rando TA. Intronic polyadenylation of PDGFRalpha in resident stem cells attenuates muscle fibrosis. Nature. 2016; 540:276-279 